\title{
Lecturer E-learning Training: The Role of Social Exchange Theory
}

\author{
Riza Bahtiar Sulistyan \\ STIE Widya Gama Lumajang \\ Email: rizabahtiars@gmail.com
}

\begin{tabular}{lll}
\hline Submission : & Review : & Publication : \\
$1^{\text {st }}$ April 2020 & $13^{\text {th }}$ June 2020 & $28^{\text {th }}$ Augustu 2020 \\
\hline
\end{tabular}

\begin{abstract}
Abstrak
The existence of the Covid-19 pandemic is able to change the organizational system that is already running normally. These changes have a profound impact on the human resources of the organization for security reasons. Not all organizations are ready to accept these changes, so there needs to be a special system that is used to keep the organization running normally. With reference to the development of social exchange theory, that training can improve the abilities of employees and the positive results will return to the organization. In this case there is a social exchange between the organization and its human resources. The impact of covid-19 is also felt at the tertiary level in Indonesia. The method used is the preparation, implementation, and evaluation stages. The participants of this training are all lecturers of STIE Widya Gama Lumajang, East Java. The training results show that there is an increase in ability before and after training. Organizations are not worried about changes in the method of the online learning system that has been established.
\end{abstract}

\section{Keyword: Training, Social Exchange Theory, E-Learning.}

\section{INTRODUCTION}

In the modern era, the use of technology is very necessary to support the smooth running of work. The obstacles faced in completing the work will be able to find solutions via the internet by searching for websites related to these problems (Sulistyan, 2017). However, the main problem is when human resources in an organization do not yet have skills in using the internet (Hartanti, 2019). If this happens, there will be discomfort at work. The negative impact later on employees will tend to leave their jobs or even leave the organization (Sulistyan, 2018; Sulistyan, Ermawati, Hidayat, Lukiana, \& Kasno, 2019).

World organizations have undergone many shifts due to covid-19. This was completely unexpected and even disturbed billions of human resources in the world. Organizations and their human resources have been forced to change their patterns of work (Sanders, Nguyen, Bouckenooghe, Rafferty, \& Schwarz, 2020). The Covid-19 pandemic has also caused social problems and hit an economic crisis in service organizations. For security reasons, many employees have to work remotely to keep services running (Bartsch, Weber, Büttgen, \& Huber, 2020; Wajdi, Ubaidillah, et al. 2020; Wajdi, Kuswandi, et al. 2020) . providing services online, a fast response is needed so that user loyalty remains or even increases(Islam \& Rahman, 2017). Quick response is very important if there are reviews from users (Pelsmacker, Tilburg, \& Holthof, 2018). 
The impact of the Covid-19 pandemic has also occurred in all universities in Indonesia. One of the efforts of the government in overcoming or breaking the chain of the spread of Covid-19 is by reducing community gathering. Therefore, according to the circular of the Minister of Education and Culture number 3 of 2020, activities that were previously carried out face-to-face are transferred to online. This transition system also occurs in private universities in East Java (Suyono, 2020). There are problems in several universities related to the online system. Not only lecturers, but also students who experience many obstacles (Widayati, 2020). Among students, if the online lecture system increases, student interest in learning will decrease (Mardesci \& Mardesci, 2020). Problems related to the online system also occur at STIE Widya Gama Lumajang, where lecturers also still need special training, in order to improve their ability to provide lecture material online.

Training in using the online learning system in tertiary institutions using e-learning if it is not immediately implemented will cause the learning system to experience many obstacles, because not all lecturers understand and know the benefits. Even though during the Covid-19 pandemic it was demanded to implement an online learning system (Pamungkas, Win, Astuti, Silalahi, \& Setyawati, 2020). There are many benefits that an organization can get if it provides training to improve the capabilities of its human resources. Later training will also have a positive impact on organizational development. This is in accordance with the development of social exchange theory in several studies on training in an organization (de Grip, Fouarge, Montizaan, \& Schreurs, 2020; Sok, Blomme, Ruiter, Tromp, \& Lub, 2018; Sulistyan, Ermawati, \& Ariyono, 2019; Sulistyan, Ermawati, Hidayat, et al., 2019; Sulistyan, Setyobakti, \& Darmawan, 2019). Social exchange theory in this case was developed in elearning training activities for lecturers in the presence of the Covid-19 pandemic. The hope of this training is that the learning process will be effective and efficient and avoid Covid-19.

\section{IMPLEMENTATION METHODS}

The method used in this training uses three stages, namely the preparation stage, the implementation stage, and the evaluation stage (Sulistyan, Setyobakti, et al., 2019). The preparation stage is carried out by paying attention to their level of understanding and problems regarding the online learning system. This stage is to see what methods will be used in the implementation of the training. The preparation stage also identifies the level of readiness of the trainees for a bold learning system. The second stage is the implementation of STIE Widya Gama Lumajang lecturer training. The training is divided into 2 stages to be more effective in delivering the material and its practice. The third stage is evaluation to determine the level of understanding of the training participants and measure the level of success. The participants of this training were 57 lecturers of STIE Widya Gama Lumajang. By using a census sample, evaluation is carried out by providing tests and questionnaires on the level of understanding of the material presented to all training participants. The success rate of training is assessed by the average value with the following classifications: (1) Low (0-50), (2) Moderate (51-75), (3) High (76-100).

\section{RESULTS AND DISCUSSION}

This training was attended by 29 male lecturers and 28 female lecturers. As seen from the NIDN, the training participants were very dominant, namely 56 lecturers with NIDN and 1 NUP. Most of the lecturers have functional positions of expert assistants as many as 30 people and 21 teaching staff, while those who have functional positions of lector are 6 people. The results of the training activities can be seen in the following three stages: 


\section{a. Preparation Phase}

The preparatory stage which was carried out by identifying the understanding showed that there was still minimal understanding of the online learning system. The problem that arises is that there is unpreparedness in using this system, so special training is needed and there is assistance in e-learning practice. The details can be seen in the following table:

Table 1. Results of the Preparation Stage Analysis

\begin{tabular}{|c|l|c|c|}
\hline No & \multicolumn{1}{|c|}{ Description of the stages } & Total & Percentage \\
\hline 1. & Identification of understanding & & \\
\hline & Understand & 10 & $17,5 \%$ \\
\hline & Do not understand & 47 & $82,5 \%$ \\
\hline 2. & Problem Indentification & & \\
\hline & Online readiness & 6 & $10,5 \%$ \\
\hline & Online unpreparedness & 51 & $89,5 \%$ \\
\hline
\end{tabular}

Source: Processed data, 2020

Based on table 1 it can be explained that the level of understanding of the online learning system is still a lot that does not understand, besides that online unpreparedness is still high.

b. Implementation Stage

This stage is carried out by delivering material and practice. The delivery of material is very useful for the introduction of e-learning and provides knowledge about the benefits obtained. Practices are used to support the material and change the mindset of the participants, which was previously done face-to-face, now online. The implementation stage is described in the table as follows:

Table 2. Result of Implementation Stage

\begin{tabular}{|c|l|c|}
\hline No & \multicolumn{1}{|c|}{ Description of the stages } & $\begin{array}{c}\text { Implementation } \\
\text { Stage }\end{array}$ \\
\hline 1. & Theory & \\
\hline & Introduction and explanation of the benefits of e-learning & 15 minute \\
\hline & Introduction to e-learning features & 45 minute \\
\hline 2. & Practice & 30 minute \\
\hline & E-learning registration for each participant & 30 minute \\
\hline & Experiment with several e-learning features & 60 minute \\
\hline & Upload material & 60 minute \\
\hline & Upload question & 90 minute \\
\hline & Experiments of the e-learning system for students & \\
\hline
\end{tabular}

Source: Processed data, 2020

Table 2 shows that the practice of using e-learning takes a long time, because it uses quite a lot of features.

c. Evaluation Stage

The evaluation stage is to assess the level of understanding of the participants with the following results:

Table 3. Result of Evaluation Stage

\begin{tabular}{|c|l|c|}
\hline No & \multicolumn{1}{|c|}{ Evaluation Description } & Value \\
\hline 1. & Retention of material & 80 \\
\hline 2. & Online readiness & 90 \\
\hline 3. & Smooth practice & 60 \\
\hline & Mean & 76 \\
\hline
\end{tabular}


Source: Processed data, 2020

From the results described in table 3 , it can be concluded that this value is good. The highest score was on online readiness descriptions, then material understanding, and the lowest score was practice fluency.

Training is able to have a positive impact in increasing the ability of STIE Widya Gama Lumajang lecturers. This can be seen in the ability of lecturers before and after training which tends to increase. Social exchange theory approach (Miles, 2012; Sulistyan, Ermawati, Hidayat, et al., 2019) in training activities it has proven that there is an exchange between human resources owned by the organization. STIE Widya Gama Lumajang provides opportunities for lecturers to take part in training and its impact is the readiness of lecturers to follow the regulations of the Minister of Education and Culture related to online learning systems.

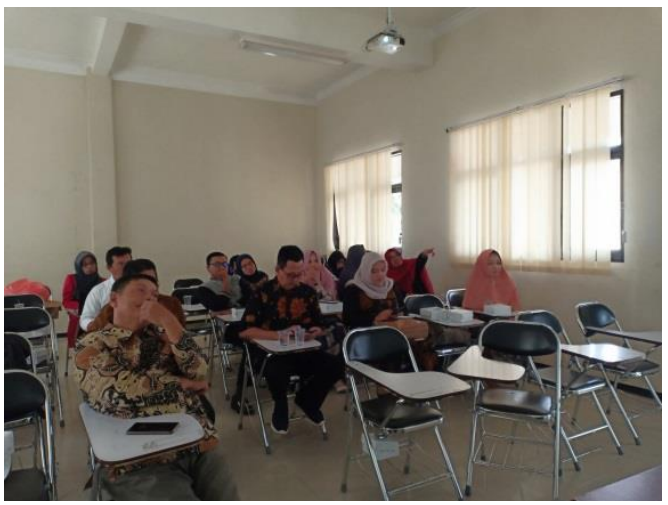

Figure 1. Preparation Phase

Source: STIE Widya Gama Lumajang 2020

The preparation stage shows that many lecturers do not understand e-learning which will be used for online learning. This is because the learning system that has been implemented is face-to-face or offline. E-learning has also been developed in recent years at STIE Widya Gama Lumajang, so that not all lecturers are able to operate it. However, after the training was carried out, the level of understanding of the lecturers increased.

The preparation stage also identifies the level of unpreparedness of the lecturer in the online learning system through e-learning. Many are not ready with this system, because in addition to being new for lecturers, there are also quite a lot of features that need to be learned. Various reasons emerged, namely not being ready because they had never used it, not being ready because of the lack of information, and the many tasks that became a burden for the lecturers not having time to study the system. The results of the training had a positive impact in increasing the readiness of lecturers to use the e-learning that had been provided.

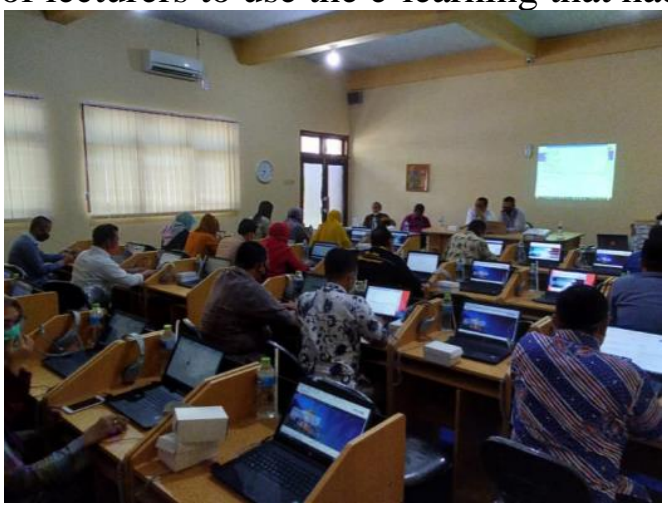

Figure 2. Implementation Stage 


\section{Source: STIE Widya Gama Lumajang 2020}

The training began with the provision of material starting from the introduction and explanation of the benefits of e-learning. It takes a lot of time because apart from something new for some of the lecturers, it is also due to the lack of information they have obtained so far regarding e-learning. Submission of material is continued with the introduction of features in the e-learning menu. The obstacle in this delivery is the large number of features used, causing confusion for the training participants. The re-delivery of the explanation of elearning features makes this activity ineffective.

The e-learning practice starts from registering each participant to have an e-learning account. Registration is also done by filling in the biodata of each lecturer and uploading a profile photo. There were a few obstacles in this registration activity because it was related to the personal data of each lecturer. The practice was continued by experimenting with several e-learning features. These features include the upload material menu, fill in learning outcomes, upload videos, set time duration, and other menus. The number of menus provided is an obstacle in this process. However, the solution is in the form of an explanation of the features that will be used in learning.

The practice of uploading material and questions must be fully understood by all participants, because the key to minimal e-learning is the existence of materials and questions for learning evaluation. Materials and questions can be in the form of powerpoint files (ppt), pdf, doc, video, or other types. The questions can be arranged randomly, with a certain time duration. After everything is uploaded, an e-learning experiment is conducted for students. Simulations are carried out by involving several lecturers to become students and carry out the learning process as expected.

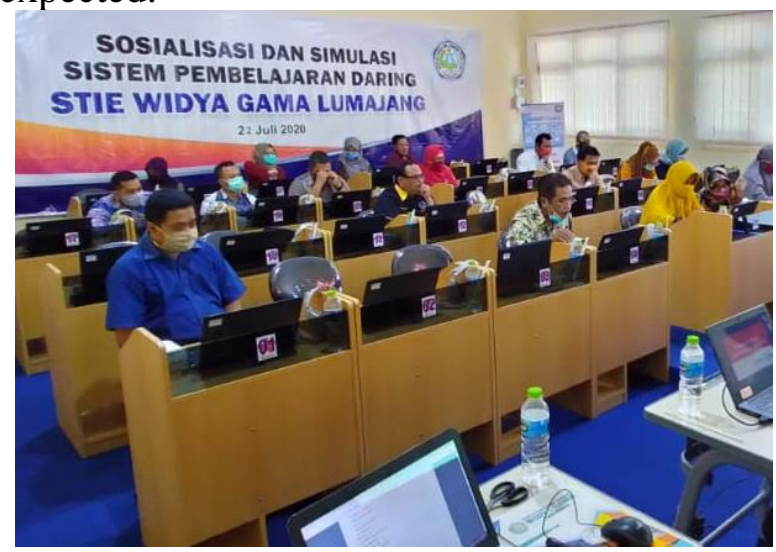

Figure 3. Evaluation Stage

Source: STIE Widya Gama Lumajang 2020

The last stage is the evaluation of the e-learning training participants. The results show that the average value is as expected, namely good value. However, if seen in detail, further training is needed to discuss more deeply related to e-learning. The participants' understanding of the material was very good and much better than before the training. Training participants are also better prepared for online learning than before the training. However, the fluency of the participants in practice still needs to be improved and requires a habit of using e-learning.

\section{CONCLUSION}

Training has a positive impact on the organization. The problem of changing the learning system due to the Covid-19 pandemic to online can be overcome with a training 
approach in accordance with the explanation of the social exchange theory. This training activity provides feedback from the training participants to the organization. There are differences in the level of understanding and high readiness from before and after training.

\section{REFERENCES}

Bartsch, S., Weber, E., Büttgen, M., \& Huber, A. (2020). Leadership matters in crisisinduced digital transformation: how to lead service employees effectively during the COVID-19 pandemic. Journal of Service Management. doi: 10.1108/josm-05-20200160

de Grip, A., Fouarge, D., Montizaan, R., \& Schreurs, B. (2020). Train to retain: Training opportunities, positive reciprocity, and expected retirement age. Journal of Vocational Behavior, 117, 103332. doi: 10.1016/j.jvb.2019.103332

Hartanti, N. T. (2019, 30 November 2019). Peningkatan Keterampilan Aplikasi Komputer menggunakan Internet dan Ms. Office untuk Guru TK (IGTKI) Yogyakarta. Paper presented at the Seminar Hasil Pengabdian Masyarakat 2019, Yogyakarta.

Islam, J. U., \& Rahman, Z. (2017). The impact of online brand community characteristics on customer engagement: An application of Stimulus-Organism-Response paradigm. Telematics and Informatics, 34(4), 96-109. doi: 10.1016/j.tele.2017.01.004

Mardesci, H., \& Mardesci, A. (2020). Pengaruh Perkuliahan dengan Metode dalam Jaringan (Daring) terhadap Minat Belajar Mahasiswa (Studi Kasus pada Program Studi Teknologi Pangan Universitas Islam Indragiri). Jurnal Pendidikan: Riset \& Konseptual, 4(3), 357-365. doi: 10.28926/riset_konseptual.v4i3.22

Miles, J. A. (2012). Management and Organization Theory (1 ed.). San Francisco: JosseyBass.

Pamungkas, P. D. A., Win, H. A., Astuti, C. W., Silalahi, E., \& Setyawati, R. K. (2020). Pelatihan Daring Optimalisasi Pemanfaatan E-Learning dalam Mendukung Pembuatan Soal Ujian Daring bagi Dosen. Jurnal Karya untuk Masyarakat, 1(1), 110.

Pelsmacker, P. D., Tilburg, S. V., \& Holthof, C. (2018). Digital marketing strategies, online reviews and hotel performance. International Journal of Hospitality Management, 72, 47-55. doi: 10.1016/j.ijhm.2018.01.003

Sanders, K., Nguyen, P. T., Bouckenooghe, D., Rafferty, A., \& Schwarz, G. (2020). Unraveling the What and How of Organizational Communication to Employees During COVID-19 Pandemic: Adopting an Attributional Lens. The Journal of Applied Behavioral Science, 56(3), 289-293. doi: 10.1177/0021886320937026

Sok, J., Blomme, R. J., Ruiter, M. D., Tromp, D., \& Lub, X. D. (2018). Home to work spillover and turnover intentions The mediating role of training and development practices. European Journal of Training and Development, 42(3/4), 246-265. doi: 10.1108/EJTD-07-2017-0060 
Sulistyan, R. B. (2017). Website Management Training Tourism Village in Sumber Pakel Padang District Lumajang. International Journal of Society Development and Engagement, 1(1), 120-128. doi: 10.29138/scj.v1i2.587

Sulistyan, R. B. (2018). Kondisi Lingkungan Pekerjaan Sebagai Ukuran Kesetiaan Pada Organisasi. Wiga : Jurnal Penelitian Ilmu Ekonomi, 8(1), 32-41.

Sulistyan, R. B., Ermawati, E., \& Ariyono, K. Y. (2019). Manajemen Retensi dalam Upaya Mempertahankan Karyawan melalui Dorongan Kepuasan dan Komitmen. Wiga : Jurnal Penelitian Ilmu Ekonomi, 9(2), 87-98. doi: 10.30741/wiga.v9i2.464

Sulistyan, R. B., Ermawati, E., Hidayat, Z., Lukiana, N., \& Kasno. (2019). Retention Management as an Effort to Overcome the Intention of Account Officers to Stop the Company. Journal of Advanced Research in Dynamical and Control Systems, 11(12), 17-25. doi: 10.5373/jardcs/v11i12/20193207

Sulistyan, R. B., Setyobakti, M. H., \& Darmawan, K. (2019). Strategi Pemberdayaan Masyarakat melalui Program Pembentukan Destinasi Wisata dan Usaha Kecil. Empowerment Society, 2(2), 1-7. doi: 10.30741/eps.v2i2.457

Suyono. (2020). Manajemen Pembelajaran Berbasis Daring dalam Rangka Memutus Mata Rantai Penularan Covid-19 Di Perguruan Tinggi Swasta Lembaga Layanan Perguruan Tinggi (LLDIKTI) Wilayah VII. Ed-Humanistics, 5(1), 662-666.

Wajdi, Muh Barid Nizarudin, Iwan Kuswandi, et al. 2020. "Education Policy Overcome Coronavirus, A Study of Indonesians." EDUTEC: Journal of Education And Technology 3(2): 96-106.

Wajdi, Muh Barid Nizarudin, M Burhanuddin Ubaidillah, et al. 2020. "Pendampingan Redesign Pembelajaran Masa Pandemi Covid-19 Bagi Tenaga Pendidik Di Lembaga Pendidikan Berbasis Pesantren Di Jawa Timur." Engagement: Jurnal Pengabdian Kepada Masyarakat 4(1): 266-77.

Widayati, S. (2020). Respon Mahasiswa Pada Proses Pembelajaran Mata Kuliah Daring. Child Education Journal, 2(1), 48-52. 